fed rats. The spleens of rats with lower calcium intakes showed a weight gain during gestation which disappeared during the subsequent lactation.

7. Fertility of the dam and mothering instinct were not impaired, even in severe calcium deficiency. The weight of the young at birth and the number of young in a litter were not affected by the level of calcium intake by the dam. Weaning weights of young from severely deficient dams were lower.

\title{
REFERENCES
}

Bakex, S. L., Butterworth, E. C. \& Langley, F. A. (1946). Biochem. J. 40, 391.

Bodansky, M. \& Duff, V. B. (1941 a). $\mathscr{F}$. Nutrit. 21, 179 .

Bodansky, M. \& Duff, V. B. (1941 b). F. Nutrit. 22, 25.

Boelter, M. D. D. \& Greenberg, D. M. (1943). F. Nutrit. 26, 105.

Cox, W. M. \& Imboden, M. (1936). f. Nutrit. I1, I47.

McLean, F. C. \& Bloom, W. (1941). Arch. Path. 32, 315.

Perlman, P. L. \& Leonard, S. L. (1947). Proc. Soc. exp. Biol., N.Y., 66, 24.

Simmonds, N. (1924). Amer. Y. Hyg. 4, I.

Thomson, W. (1936). F. Hyg., Camb., 36, 24.

Warnock, G. M. \& Duckworth, J. (1944). Biochem. F. 38, 220.

\section{A Balance Sheet of the Estimation of Energy Intake and Energy Expenditure as Measured by Indirect Calorimetry, Using the Kofranyi-Michaelis Calorimeter}

\section{By R. PASSMORE, J. G. THOMSON AND GRACE M. WARNOCK}

WITH THF, ASSISTANCE OF

\author{
CAROL M. DIXON, A. H. KITCHIN, G. SMITH, MARGARET C. VAUGHAN \\ AND J. A. WATT \\ Department of Public Health and Social Medicine, University of Edinburgh, \\ and the Scientific Adviser's Division, Ministry of Food, London
}

(Received 30 July I 95I)

In a recent review, an expert committee of the Food and Agricultural Organization of the United Nations (1950) sets out existing physiological knowledge of energy requirements from food in relation to practical rationing problems. Throughout their report the committee again and again draw attention to the gaps in present knowledge and to the need for further investigations. One method of assessing food requirements is the measurement of energy expended (in terms of heat loss) during various physical activities. Direct measurements of the heat loss of man under varying conditions have been made. Such methods of direct calorimetry possess the advantage of great accuracy, but human calorimeters are expensive and require great skill in use. Though they are invaluable as instruments for determining basic physiological principles, they can be of little help in tackling problems of energy requirements under conditions of everyday life. Indirect calorimetry (the assessment of energy expenditure 
from measurements of rates of oxygen consumption) is a more practical possibility but, even by these means, the drawing up of an energy balance-sheet presents great difficulties.

The metabolic cost of numerous activities has been accurately determined by measurement and analysis of samples of expired air collected in Douglas bags. The size and clumsiness of these bags limit their range of use in everyday life; their small capacity in relation to lung-ventilation rates limits the time for which one bag can be used. For these reasons estimations of the cost of complicated activities, such as take place in modern industry, are always difficult and time consuming, so much so as to be often wellnigh impossible. Many attempts to draw up a daily cost of energy expenditure by persons of different occupations have been made; these have been reviewed and summarized by Orr \& Leitch (1937-8). Such estimates, though probably essentially correct, depend of necessity on much guess-work and have a wide range of error.

The development by Kofranyi \& Michaelis (1940) of a compact, light, portable calorimeter is a great technical advance. This instrument is essentially a dry gas-meter, weighing only $4 \mathrm{~kg}$ and easily carried on the subject's back; it measures directly the volume of the expired air, and at the same time collects a continuous sample of a small constant fraction, which is available for subsequent analysis. The calorimeter has already been used in Germany for a big survey of energy expenditure in industry (Lehmann, Müller \& Spitzer, 1949-50), and for a detailed study of the metabolic cost of the housewife's manifold activities (Droese, Kofranyi, Kraut \& Wildeman, 1949-50). Similar studies have not been made in industry in this country.

In this laboratory Orsini \& Passmore (I95I) have compared results of the cost of a range of simple standardized work, using both Douglas bags and the KofranyiMichaelis calorimeter and found a good agreement between the two. But before undertaking a survey of the energy cost of various activities in British industries, we thought fit to test the instrument and the reliability of methods of indirect calorimetry in a laboratory study. The plan was that the subjects of the experiments should live in the laboratory for a period, during which a complete record of activities would be made, and the cost of sample activities determined by means of the calorimeter. In this way estimates of total energy expenditure could be obtained. At the same time accurate measurements of food intake would be made, and an assessment of the total calories available for expenditure provided. If a reasonable agreement were found between these two estimates, this would provide a measure of the reliability of the methods, and might provide a basis of confidence for results obtained later in industry under conditions less suitable for prolonged observations.

\section{METHODS}

General. Five students, men between 19 and 25 years, acted as subjects and lived in the Department for 2 weeks. During 13 consecutive days, a detailed time record was kept of all their activities, all food consumed was weighed and the metabolic cost of about thirty separate activities determined for each subject. The plan was to spend the first 3 days in sedentary life within doors, then to have 5 days of hard 
physical work, and finally a second period of 5 days of sedentary life. 'The two sedentary periods passed according to plan. The subjects spent the whole time in light activities and undertook no hard work. Except on two or three occasions when they went on small errands, they did not leave the building.

For the hard physical activity, outdoor track-walking was chosen. This is hard work, a steady and continuous activity, whose metabolic cost can easily be determined. The movements involved are those to which the subjects were of necessity accustomed in their everyday life. Unfortunately, the weather proved unkind, and wind and rain made conditions variable and often unfriendly on the grass track 103० yd. around the University athletic ground. On one afternoon conditions were so bad that climbing up and down stairs in the laboratory was substituted for walking. Unfortunately three of the subjects developed blisters and minor orthopaedic trouble which on occasions restricted activity. Further, John, one of the fittest, developed mumps in the middle of the experiment and was only available for heavy work on 3 days, during which he walked 50 miles. Evan, whose feet prevented his exercising on one day, walked 52 miles. Iain, George and Alistair walked 66, 71 and 76 miles respectively, spread out over the 5 -day period. The speed of walking varied between 4.2 and $4.8 \mathrm{~m}$.p.h. In addition to the walking, a dance was held at the end of the work period. The metabolic cost of the various dances was determined without difficulty. One subject, George, played two games of Rugby football. The direct cost of these games could not be measured, but an estimate was made by comparison with other activities.

Choice of diet and estimation of its energy value. Because of uncertainties about the accuracy of estimates from food tables it was decided that the energy value of the diets should be obtained by chemical analysis of duplicate samples. To allow each subject to choose the whole of his diet quantitatively and qualitatively was impractical because of the very large number of analyses which such a procedure would have involved. Thus, to reduce the number as far as possible, about half of the total energy value of the diet each day was provided as a basic diet which was exactly the same for each subject. For the remainder of the diet each man was allowed to eat as much as he liked of bread, butter, sugar, bramble jelly, processed cheese and milk. Beer or cider was available at the evening meal. All these, as well as a sample of the basic diet for each day, were analysed separately. The energy values were calculated from the chemical analysis for moisture, protein, fat and ash. Carbohydrate was obtained 'by difference' and the energy value estimated from the carbohydrate, fat and protein content using the Atwater factors, 4, 9, 4.

The eating habits of the men had been observed during a preliminary study, and the pattern of the meals during the $\mathrm{r} 3$ experimental days was as close to this as possible.

The selection of dishes was in agreement with the likes and dislikes of the subjects. The pattern of the daily diet was as follows:

Breakfast: porridge or cereal and fruit juice; cooked dish.

Lunch: meat, fish, cheese or egg dish; potato and other cooked vegetable; baked or steamed pudding; biscuits. 
Tea: cake or biscuit.

Dinner: meat, fish, cheese or egg dish; potato and other cooked vegetable or salad; hot or cold dessert, e.g. trifle, fruit pie.

At each meal weighed quantities of bread, butter, cheese, sugar, bramble jelly and milk were placed before each subject so that he could eat as much as he desired of any of these six foods. The amount eaten by each was ascertained by weighing what was left at the end of the meal. All foods were placed in covered vessels to avoid loss of weight by evaporation. Cellophane bags were found to be ideal for the bread. Either coffee or tea was served with each meal. No allowance was made for the energy value in either tea or coffee.

Using this technique it was possible to present a varied menu each day and also to limit the number of chemical analyses to about twenty samples for the whole period. Care was taken to avoid the use of foods difficult to sample, e.g. very fat meat or bacon, and for the same reason, frying as a method of cooking was avoided. Composite dishes, such as fruit pies, meat cooked with vegetables as in stews, trifles and salads, were prepared by weighing each ingredient for each subject and also for the sample for analysis. Where cooked, these were weighed and served in individual Pyrex dishes. This technique proved to be acceptable to the subjects, and, as none left any of the basic diet on his plate, was equally successful from our point of view.

One subject, John, did not consume the basic diet for 5 days while he was suffering from mumps. Weight records of each item eaten were kept and, during that period, the estimate of the energy value of his diet was made from food tables. While ill he consumed mostly milk, sugar, eggs, fruit juices, bread and butter. The energy value of these particular foods is fairly definite and the error introduced from this method of calculation should be very small.

Indirect calorimetry. Basal metabolic rates, and rates lying at rest, were determined with a Benedict-Roth spirometer, assuming a respiratory quotient of 0.78 . All other rates were obtained using the Kofranyi-Michaelis calorimeter. Gas analyses were carried out in duplicate using the Haldane apparatus. All estimates covered periods of at least 6 and at most $15 \mathrm{~min}$, the average being $10 \mathrm{~min}$. As conditions varied owing to the weather on the outdoor track, estimations on each subject were made each morning and afternoon when walking was undertaken. Speeds varied slightly in the different periods. For each subject the range of cost for sitting activities was small, and for light indoor activities not great. Accordingly, selected values have been chosen for sitting activities and for light indoor activities. These have been used throughout. To split up these two groups into their separate activities would have involved an immense labour and, in the conditions of our experiment, would probably add little to the accuracy.

Record of activities. The problem of recording, from minute to minute and from day to day for I 3 days, the multifarious activities of five active young men seemed, on first consideration, to demand the assistance of five observers. Under other conditions, with less intelligent or less enthusiastically co-operative subjects this is probably so. In the present investigation, however, each subject acted as his own observer, timing and recording his activities in great detail on a specially designed 
activity chart. Each chart, foolscap size, covered $8 \mathrm{~h}$ of the day, providing a 3 in. square for each hour. The hour squares were subdivided into sixty smaller squares for recording by minutes and a small compartment for notes on the activities engaged in during the hour. The minute squares were quickly filled in with red or blue pencil, a change of colour indicating a change of activity. Code letters of the various activities indicated the meaning of each change of colour from blue to red or red to blue. These code letters were explained in a legend at the bottom of the chart, but it was possible for the subject to record any doubtful or undefined activity by an additional code letter, the meaning of which was then added to the legend. Two $8 \mathrm{~h}$ charts recorded the details of each waking day and from them it was possible to calculate the total time spent daily on each of the various activities recorded. To guard against possible forgetfulness or inaccuracy when out of the Department, each subject had a notebook in which details and time were noted for later transcription to the chart.

\section{RESULTS}

Metabolic cost of various activities. Table I shows the results of all the estimations of metabolic cost during the 13 days, except those obtained on John when febrile, which are shown separately in Table 2. Tables 3-7 record, for each subject for the total period of 13 days, the total time spent in each classified activity, the estimated cost of the activity and the total calories expended. The activities are arranged according to the total calorie expenditure over the period. The justification for grouping all sitting activities together and all light indoor activities together has already been explained. The total period spent in bed each night, from the time of lying down until rising in the morning, was costed at the basal metabolic rate on the assumption that any period when the metabolic rate was above the basal rate would approximately balance the period during sleep when calorie expenditure might be expected to fall a little below the basal rate. Any other period during the day which was spent lying down was recorded under the heading 'lying at rest'.

'Indoor walking' was assumed, from careful observation, to be carried out at approximately 3 m.p.h., except by George, who generally moved somewhat faster than the others.

'Stair climbing' covers the routine daily movements about the building carried out as nearly as possible at roo stairs/min whether climbing or descending. 'Stair exercise', on the other hand, covers a period of carefully timed and controlled exercise which replaced 'track walking' on a particularly inclement afternoon. The apparently large amount of time spent in climbing stairs is due to the subjects having to live and sleep at the top and feed on the ground floor of a building not provided with a passenger lift.

Energy balance of the subjects. Table 8 shows the energy value of the food consumed and Table 9 the final balance for each subject. For John, George and Evan, who each gained a little weight up to $0.34 \mathrm{~kg}$, the estimated energy value of the food absorbed is up to $2100 \mathrm{Cal}$. above the estimated expenditure. This represents an average daily difference of less than $\mathrm{r} 60 \mathrm{Cal}$. or up to $5 \%$ of the total. Alistair was 
estimated to have used $5000 \mathrm{Cal}$. less, and Iain $3100 \mathrm{Cal}$. more, than he ate. But for Alistair, against the excess of food, there is the $2.66 \mathrm{~kg}$ gain of weight; against Iain's food deficit a loss of $2.49 \mathrm{~kg}$ of body-weight can be set. Any attempt to convert

Table I. Metabolic cost of various activities (in Cal./min)

\begin{tabular}{|c|c|c|c|c|c|}
\hline Activity & $\begin{array}{c}\text { John } \\
\text { (67 in., } 131 \text { lb.) }\end{array}$ & $\begin{array}{c}\text { George } \\
(68 \text { in., } 152 \text { lb.) }\end{array}$ & $\begin{array}{c}\text { Alistair } \\
\text { (72 in., } 166 \text { lb.) }\end{array}$ & $\begin{array}{c}\text { Evan } \\
\text { (72) in., } 175 \mathrm{lb} .)\end{array}$ & $\begin{array}{c}\text { Iain } \\
(75 \text { in., } 183 \text { lb.) }\end{array}$ \\
\hline Basal & $I \cdot I 2, I \cdot I 3, I \cdot I I$ & $I \cdot 20,1 \cdot 15,1 \cdot 26$ & $I \cdot I 4, I \cdot 09, I \cdot 2 I$ & $I \cdot 31,1 \cdot 16, x \cdot 27$ & $I \cdot 22, I \cdot 27,1 \cdot 20$ \\
\hline Lying at ease & $I \cdot 4, I \cdot 4, I \cdot 2, I \cdot 4$ & $\mathrm{I} \cdot 4, \mathrm{I} \cdot 6, \mathrm{I} \cdot 4$ & $I \cdot 4, I \cdot 6, I \cdot 5$ & $1 \cdot 5, x \cdot 6, x \cdot 6$ & $I \cdot 5, I \cdot 4, I \cdot 3$ \\
\hline \multicolumn{6}{|l|}{ Sitting: } \\
\hline At ease & $1 \cdot 5$ & $\mathrm{r} \cdot 9$ & $\mathrm{x} \cdot 8$ & 1.9 & $2 \cdot 0$ \\
\hline Calculating & $x \cdot 5,1 \cdot 2,1 \cdot 7$ & $2 \cdot 3$ & $2 \cdot 0$ & $2 \cdot 0$ & $2 \cdot I$ \\
\hline Reading & - & $2 \cdot 2$ & I.9 & - & - \\
\hline \multirow{2}{*}{$\begin{array}{l}\text { Writing a letter } \\
\text { Listening to the Bare }\end{array}$} & - & $1 \cdot 9$ & $2 \cdot 2$ & $2 \cdot 0$ & $2 \cdot 2$ \\
\hline & - & - & - & $2 \cdot 0$ & $2 \cdot 5$ \\
\hline $\begin{array}{l}\text { Playing Canasta } \\
\text { Pand }\end{array}$ & $2 \cdot 0$ & $2 \cdot I$ & $2 \cdot \mathbf{I}$ & $1 \cdot 9$ & $2 \cdot 5$ \\
\hline Unspecified (selected value) & $\mathrm{I} \cdot 8$ & $2 \cdot 2$ & $2 \cdot 1$ & $2 \cdot 0$ & $2 \cdot 3$ \\
\hline Standing at ease & $x \cdot 5$ & $2 \cdot 2,2 \cdot 1$ & $2 \cdot 0,2 \cdot 3$ & $2 \cdot 5,2 \cdot 4$ & $I \cdot 8, I \cdot 9$ \\
\hline \multicolumn{6}{|l|}{ Light indoor activities: } \\
\hline Peeling potatoes & - & $2 \cdot 7$ & - & - & - \\
\hline $\begin{array}{l}\text { Washing dishes } \\
\text { Washing socks }\end{array}$ & - & - & $3 \cdot 7$ & $3 \cdot 4$ & 3.9 \\
\hline Washing socks & - & $4 \cdot \mathrm{I}$ & - & - & - \\
\hline $\begin{array}{l}\text { Cleaning shoes } \\
\text { Laboratory work }\end{array}$ & - & - & - & 3.3 & 4.7 \\
\hline \multirow{2}{*}{$\begin{array}{l}\text { Laboratory work } \\
\text { Dressing, washing, shaving }\end{array}$} & $2 \cdot 5$ & $3 \cdot 5$ & $3 \cdot 9$ & 3.9 & $3 \cdot 3$ \\
\hline & $2 \cdot 8$ & $4 \cdot 1$ & $3 \cdot 6,3 \cdot 7$ & $4 \cdot 5,4 \cdot 1$ & $3 \cdot 9,4 \cdot 2$ \\
\hline Making beds & - & - & $7 \cdot 6$ & - & - \\
\hline Unspecified (selected value) & $2 \cdot 7$ & $4^{\circ} \cdot$ & 3.8 & $4 \cdot 0$ & $4 \cdot 0$ \\
\hline \multicolumn{6}{|l|}{ Walking: } \\
\hline 2.4 m.p.h. & $4 \cdot 3$ & 47 & 3.8 & - & $5 \cdot 1$ \\
\hline \multirow{6}{*}{ Outdoors } & - & $5 \cdot 6$ & $5 \cdot 5$ & $5 \cdot 3,5 \cdot 4$ & $5 \cdot 1,5 \cdot 9$ \\
\hline & - & $8 \cdot 2$ & - & & \\
\hline & $8 \cdot 2$ & $9 \cdot 0$ & - & $10 \cdot 4, I I \cdot 3$ & $9 \cdot 8$ \\
\hline & $9 \cdot \mathbf{I}$ & $10.3,9.5,10.1$ & $9 \cdot 7,9 \cdot 8,9 \cdot 9$ & 10.7 & - \\
\hline & $10 \cdot I$ & - & 10.6 & - & $I I \cdot 0, I I \cdot 2$ \\
\hline & 10.2 & $10 \cdot 6$ & $12 \cdot 0$ & $\mathrm{II} \cdot 6$ & $I 1 \cdot 2,13 \cdot 7$ \\
\hline $\begin{array}{l}\text { Up and down } 97 \text { per min } \\
\text { stairs } 116\end{array}$ & $\begin{array}{l}6 \cdot 6 \\
8 \cdot 5\end{array}$ & $\begin{array}{l}8 \cdot 0,8 \cdot 9 \\
8 \cdot 4\end{array}$ & $\begin{array}{l}9 \cdot 6,10 \cdot 1 \\
10 \cdot 3\end{array}$ & $\begin{array}{l}9 \cdot 9,9 \cdot 5 \\
10 \cdot 4\end{array}$ & $\begin{array}{l}9 \cdot 6,9 \cdot 3,9 \cdot 0 \\
1 \times \cdot 8\end{array}$ \\
\hline \multicolumn{6}{|l|}{ Dancing: } \\
\hline Foxtrot & - & - & - & $5 \cdot 2,5 \cdot 2$ & 5.8 \\
\hline Waltz & - & 一 & $5 \cdot 7$ & - & $7 \cdot 1$ \\
\hline Rumba & - & $7 \cdot 0$ & - & - & - \\
\hline Petronella & - & $4 \cdot 7$ & - & - & - \\
\hline Eightsome reel & - & $7 \cdot 5$ & - & $8 \cdot I$ & $7 \cdot 5$ \\
\hline
\end{tabular}

Table 2. Energy expenditure of fohn, lying in bed febrile

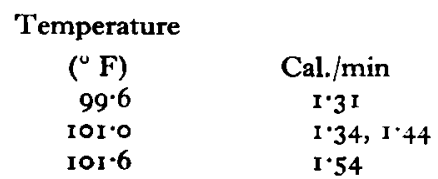

these weight changes into corresponding calories could only be the wildest guess in the absence of precise measurements of changes in body-water content.

During the first 3 days of sedentary life, all the subjects consumed more than they expended. The excess appetite was no doubt partly psychological and could be 
Table 3. Energy expenditure of Fohn over 13 days

\begin{tabular}{|c|c|c|c|}
\hline \multirow[b]{2}{*}{ Activity } & Time & \multicolumn{2}{|c|}{ Energy expenditure } \\
\hline & h $\min$ & Cal./min & Total Cal. \\
\hline Track walking & I I & $9 \cdot 2$ & 6,170 \\
\hline In bed & $56 \quad 14$ & $I \cdot I I$ & 3,750 \\
\hline Light sedentary activities & 270 & $1 \cdot 8$ & 2,920 \\
\hline Sitting at ease & $28 \quad 38$ & $1 \cdot 5$ & 2,580 \\
\hline Walking (about 3 m.p.h.) & $4 \quad 52$ & 5.0 & 1,460 \\
\hline Light standing activities & 621 & $2 \cdot 7$ & 1,030 \\
\hline Stair exercises & I 54 & $8 \cdot 5$ & 970 \\
\hline Dressing, shaving & 359 & 2.8 & 670 \\
\hline Stair climbing & I I & $7 \cdot 0$ & 430 \\
\hline Lying at rest & I 37 & $1 \cdot 4$ & 140 \\
\hline Sundry activities & 155 & 一 & 180 \\
\hline Total & 6 days & & 20,300 \\
\hline Sitting up in bed & $69 \quad 57$ & $1 \cdot 6$ & 6,720 \\
\hline Lying in bed (febrile) & $44 \quad 29$ & $x \cdot 35$ & 3,600 \\
\hline Lying in bed (afebrile) & $41 \quad 5^{8}$ & I. II & 2,800 \\
\hline Lying in bed (afebrile) (low fever) & 1128 & $1 \cdot 25$ & 860 \\
\hline Out of bed & -8 & 4.0 & 30 \\
\hline Total & 7 days & & 14,010 \\
\hline Grand total & 13 days & & 34,310 \\
\hline
\end{tabular}

Table 4. Energy expenditure of George over 13 days

\section{Activity}

Light sedentary activities

Track walking

In bed

Walking (about 3.5 m.p.h.)

Light standing activities

Dressing, shaving

Lying reading, etc.

Rugby football

Stair climbing

Dancing

Stair exercise

Standing at ease

Total

$\begin{array}{rc}\text { h } & \text { min } \\ \text { II } & 19 \\ 15 & 53 \\ \text { I } 12 & 58 \\ \text { I } & 11 \\ 13 & 57 \\ 9 & 5 \\ 18 & 28 \\ 2 & 54 \\ 2 & 22 \\ 2 & 8 \\ \text { I } & 24 \\ 3 & 20\end{array}$

13 days
Energy expenditure

\begin{tabular}{cc}
\hline Cal./min & Total Cal. \\
$2 \cdot 2$ & 14,690 \\
$9 \cdot 4$ & 8,910 \\
$1 \cdot 2$ & 8,130 \\
$6 \cdot 5$ & 7,090 \\
$4 \cdot 0$ & 3,350 \\
$4 \cdot 1$ & 2,235 \\
$2 \cdot 0$ & 2,220 \\
$10 \cdot 0$ & 1,740 \\
$8 \cdot 5$ & 1,210 \\
$-5 \cdot 4$ & 800 \\
$2 \cdot 1$ & 710 \\
& 420
\end{tabular}

Table 5. Energy expenditure of Alistair over 13 days

Activity

Light sedentary activities Track walking

In bed

Walking (about 3 m.p.h.)

Light standing activities

Lying at rest

Dressing, shaving

Stair climbing

Sitting at ease

Stair exercise

Sundry activities

Total

$\begin{array}{rc}\text { h } & \text { min } \\ 103 & 46 \\ 17 & 14 \\ 118 & 16 \\ 12 & 46 \\ 14 & 41 \\ 24 & 49 \\ 5 & 49 \\ \text { I } & 44 \\ 8 & 54 \\ 1 & 21 \\ 2 & 40\end{array}$

13 days
Energy expenditure

\begin{tabular}{cc}
\hline Cal./min & Total Cal. \\
$2 \cdot 1$ & 13,070 \\
$10 \cdot 1$ & 10,390 \\
$1 \cdot 15$ & 8,160 \\
$5 \cdot 5$ & 4,080 \\
$3 \cdot 8$ & 3,350 \\
$1 \cdot 5$ & 2,230 \\
$3 \cdot 7$ & 1,290 \\
$9 \cdot 8$ & 1,020 \\
$1 \cdot 8$ & 960 \\
10.3 & 870 \\
- & 560 \\
& 45,980
\end{tabular}


Table 6. Energy expenditure of Evan over I 3 days

Activity

Light sedentary activities

Track walking

In bed

Light standing activities

Walking (about 3 m.p.h.)

Lying at rest

Dressing, shaving

Stair climbing

Dancing

Stair exercise

Sundry activities

\begin{tabular}{|c|c|}
\hline \multicolumn{2}{|c|}{ Time } \\
\hline h & $\min$ \\
\hline 90 & 31 \\
\hline I I & 48 \\
\hline 121 & 13 \\
\hline 24 & 7 \\
\hline 6 & 33 \\
\hline $3^{6}$ & 25 \\
\hline 7 & 32 \\
\hline 2 & 44 \\
\hline 2 & 14 \\
\hline- & 5 I \\
\hline 2 & $\mathbf{I}$ \\
\hline
\end{tabular}

Total

\begin{tabular}{cc}
\multicolumn{2}{c}{ Energy expenditure } \\
\hline Cal./min & Total Cal. \\
$2 \cdot 0$ & 10,860 \\
$10 \cdot 7$ & 7,580 \\
$1 \cdot 2$ & 8,730 \\
$4 \cdot 0$ & 5,790 \\
$5 \cdot 3$ & 3,990 \\
$1 \cdot 6$ & 3,500 \\
4.3 & 1,940 \\
$10 \cdot 0$ & 1,640 \\
- & 910 \\
$10 \cdot 4$ & 590 \\
- & 470 \\
& 46,000
\end{tabular}

Table 7. Energy expenditure of Iain over 13 days

Activity

Light sedentary activities

Track walking

In bed

Light standing activities

Dressing, shaving

Walking (about 3 m.p.h.)

Stair climbing

Stair exercise

Dancing

Sitting at ease

Sundry activities

$\begin{array}{rr}\text { h } & \text { min } \\ 126 & 18 \\ 15 & 8 \\ 117 & 0 \\ 15 & 28 \\ 13 & 43 \\ 6 & 2 \\ 2 & 15 \\ 1 & 29 \\ 2 & 14 \\ 7 & 29 \\ 4 & 54 \\ 13 & \text { days }\end{array}$

Total

$\begin{array}{cc}\text { Cal./min } & \text { Total Cal. } \\ 2 \cdot 3 & 17,430 \\ 10 \cdot 3 & 10,100 \\ 1 \cdot 2 & 8,420 \\ 4 \cdot 0 & 3,710 \\ 4 \cdot 0 & 3,290 \\ 5 \cdot 5 & 2,000 \\ 9 \cdot 3 & 1,260 \\ 11 \cdot 8 & 990 \\ - & 900 \\ 2 \cdot 0 & 900 \\ - & 580 \\ & 49,580\end{array}$

Table 8. Energy value of diets (Cal.)

First sedentary

$\begin{array}{rr}\text { period } & \text { John } \\ \text { Day I } & 2,920 \\ 2 & 3,300 \\ 3 & 3,650 \\ & \text { Mean 3,290 }\end{array}$

Action period

$\begin{array}{rr}\text { Day } 4 & 4,270 \\ 5 & 3,660 \\ 6 & 3,54 \circ \\ 7 & 1,080 \dagger \\ 8 & 990 \dagger \\ & \text { Mean } 3,820 \$\end{array}$

Second sedentary

$$
\text { period }
$$

Day 9
10
11
12
13

$$
\text { Grand total } \quad 36,280
$$$$
\begin{aligned}
& \text { 1,410 } \\
& \text { 1,800† } \\
& 3,220 \dagger \\
& 3,550 \dagger \\
& 2,890 t
\end{aligned}
$$$$
4,370
$$$$
4,5301
$$$$
4,480
$$$$
4,260
$$$$
3,840
$$$$
4,300
$$$$
\text { (13 days) }
$$

George
3,140
3,690
4,010
3,610
4,330
4,040
4,340
4,050
4,0101
4,150

4,370
4,5301
4,480
4,260
3,840
4,300
53,090

Alistair
2,900
3,430
3,540
3,290

4,530
4,360
4,360
3,630
4,090
4,190

Evan
2,960
3,580
3,510
3,350
4,240
3,580
3,560
3,320
3,730
3,600

3,500
3,840
4,250
4,450
4,140
4,040
51,020

4,260
4,150
3,490
4,050
3,700
3,930
48,130

4,040

3,420

3,520

3,250

3,060

3,460

46,300

- Sedentary. † In bed-mumps. † One game Rugby football. $\$$ Average of 3 days only. 
Table 9. Total estimated energy expenditure of the five subjects over 13 consecutive days compared with energy value of the diet for the same period

\begin{tabular}{|c|c|c|c|c|c|}
\hline & John & George & Alistair & Evan & Iain \\
\hline $\begin{array}{l}\text { Estimated energy expenditure Cal.) } \\
\text { Energy value of diet (Cal.) } \\
\text { Weight changes (kg) }\end{array}$ & $\begin{array}{l}34,310 \\
36,280 \\
+0 \cdot 34\end{array}$ & $\begin{array}{r}51,510 \\
53,090 \\
+0.31\end{array}$ & $\begin{array}{r}45,980 \\
51,020 \\
+2 \cdot 66\end{array}$ & $\begin{array}{l}46,000 \\
48,130 \\
+0 \cdot 14\end{array}$ & $\begin{array}{l}49,580 \\
46,300 \\
-2 \cdot 49\end{array}$ \\
\hline
\end{tabular}

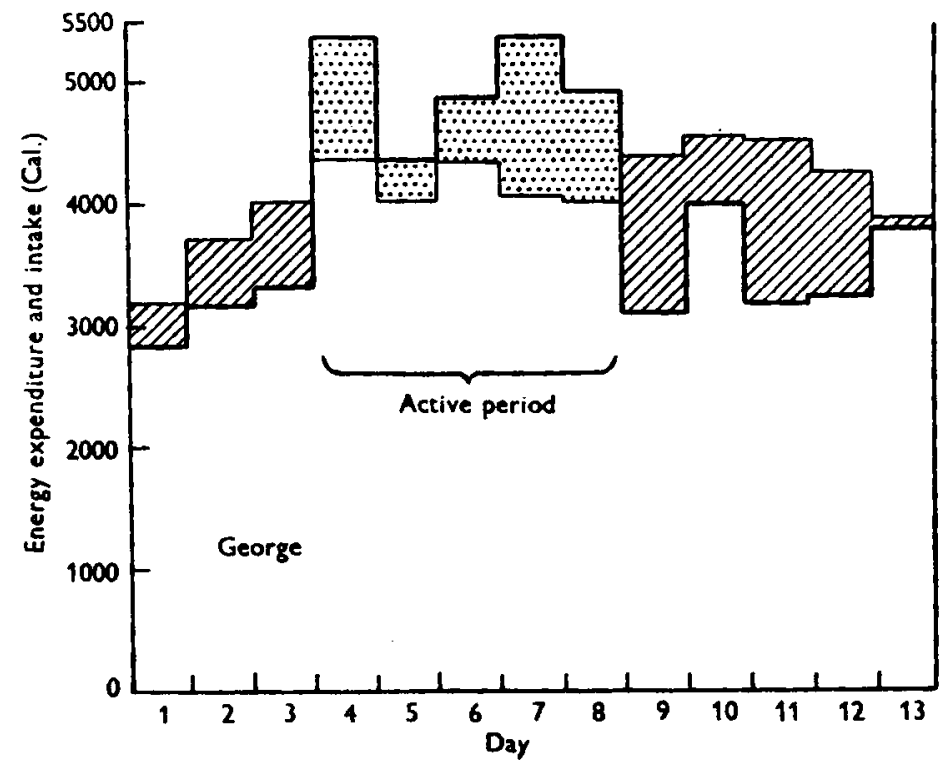

Fig. I. Energy balance for George. Thin line, daily energy intake; thick line, daily energy expenditure. Cross-hatched areas show excess intake over expenditure; stippled areas show excess expenditure over intake.

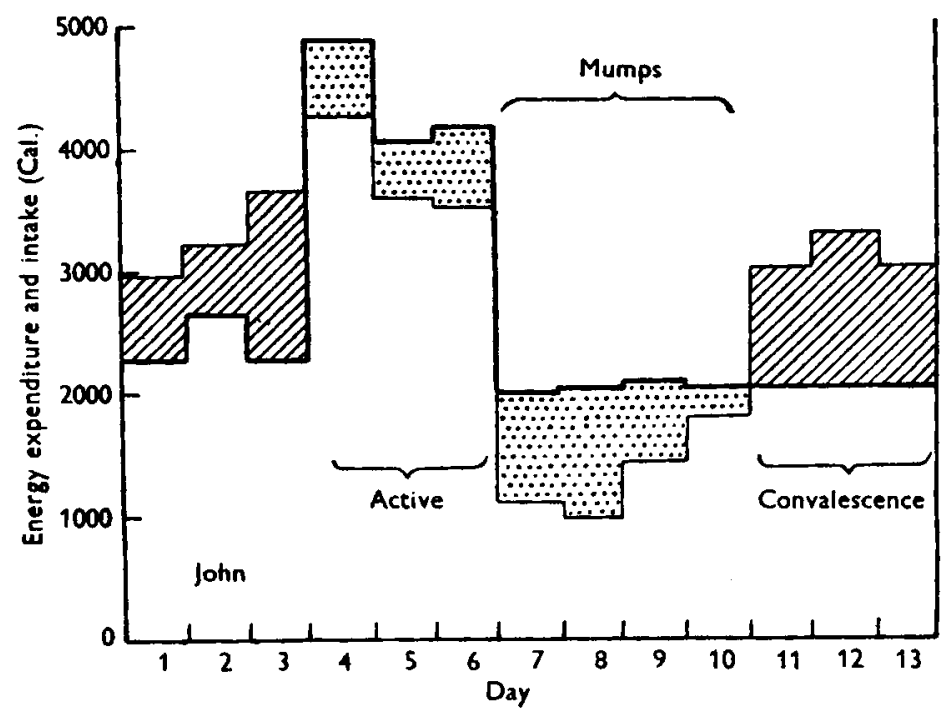

Fig. 2. Energy balance for John. Thin line, daily energy intake, thick line, daily energy expenditure. Cross-hatched areas show excess intake over expenditure, stippled areas show excess expenditure over intake. 
explained to some extent by natural relaxation at the end of term, and also perhaps as a compliment to our cook. During the 5-day exercise period, when expenditure rose as high as 6000 Cal., intakes also rose, but never to the level of output. This may be explained by simple physical fatigue. The men were just too tired to eat. The deficit was made good during the second 5-day sedentary period, when all ate each day food with an energy content a little greater than the energy expended. Fig. I shows the day-to-day variations in intake and expenditure for George. Alistair, Evan and Iain all showed essentially the same pattern. John also followed the same course until mumps developed on the 7 th day. Thereafter, till the end of the experiment, he stayed in bed with a daily expenditure remaining constantly around $2000 \mathrm{Cal}$. For the first 2 days the fever and the pain restricted food intake to about $1000 \mathrm{Cal}$., but, on the final 3 days, when convalescence was fully established, he made up the deficits with intakes of the order of $3000 \mathrm{Cal}$. Fig. 2 shows his two periods of negative balance (exercise and acute illness) and his two periods of positive balance (good appetite and convalescence). By a happy chance these two pairs equalled each other, the weight lost in the illness was regained and over the 13 days a good balance was obtained.

Table ro. Average energy expenditure (Cal.) of the five subjects during sedentary and active periods compared with recommended allowances

\begin{tabular}{|c|c|c|c|c|c|}
\hline & John & George & Alistair & Evan & Iain \\
\hline & \multicolumn{5}{|c|}{ Average energy expenditure } \\
\hline \multirow{3}{*}{$\begin{array}{l}\text { Sedentary period } \\
\text { Active period }\end{array}$} & 2400 & 3240 & 2870 & 3040 & 3080 \\
\hline & 4350 & $495^{\circ}$ & 4610 & 4650 & 5040 \\
\hline & (Food a & $\begin{array}{r}\text { Rec } \\
\text { riculture }\end{array}$ & $\begin{array}{l}\text { ended al } \\
\text { nization }\end{array}$ & United & $2 s, 1950$ \\
\hline \multirow[t]{2}{*}{ Activity: Moderate } & 3019 & 3378 & 3553 & 3725 & $3^{825}$ \\
\hline & \multicolumn{5}{|c|}{ (Canadian Council on Nutrition, 1950) } \\
\hline Sedentary & 2225 & 2425 & 2575 & 2675 & 2750 \\
\hline Moderate & $275^{\circ}$ & 2950 & 3100 & 3200 & 3275 \\
\hline Heavy & 3500 & 3700 & 3850 & $395^{\circ}$ & 4025 \\
\hline Very heavy & 4500 & 4700 & 4850 & $495^{\circ}$ & 5025 \\
\hline
\end{tabular}

Energy expenditure and reference standards. Table to shows the average expenditure of the five subjects during the sedentary and active periods set out in relation to two well-known reference standards. Allowances have been made for the age and weight according to the recommendations laid down by the Food and Agriculture Organization of the United Nations (1950) and the Canadian Council on Nutrition (1950).

It will be seen that, during the sedentary period, the energy expenditure for four of our subjects was between 600 and 900 Cal./day less than the F.A.O. recommendations. Our fifth subject, George, was, however, expending only I $50 \mathrm{Cal}$./day less during the sedentary period than the F.A.O. recommendation based on moderate activity. As has been explained earlier, George normally moved more quickly than the others. During the period of great physical activity the subjects expended between 900 and 1600 Cal./day in excess of the F.A.O. estimate.

Except for George, the energy expenditure during the sedentary period lay between the allowances recommended for sedentary occupation and moderate activity on the 
Canadian standard. During the period of great physical activity the energy expenditure of all subjects was within 300 Cal. of that estimated by the Canadian Council on Nutrition for very heavy workers.

\section{DISCUSSION}

For practical reasons it was unfortunately not possible to carry on this experiment for longer than 13 days. The inclusion of a water-balance study would have been of considerable value in the interpretation of these results, but was too complicated to include in the programme; over the short period there were differences in the initial and final body-weights, but it is impossible to estimate how far these differences represent changes in body tissue.

Two subjects showed considerable weight changes; Iain lost 2.49 kg and Alistair gained $2.66 \mathrm{~kg}$. The others all gained weight, but less than $0.34 \mathrm{~kg}$. The differences between the energy value of the food eaten and the energy expended were in agreement with these weight changes, being -3300 Cal. for Iain, +5000 Cal. for Alistair and between +1500 and +2100 Cal. for the others. When the experiment had to be terminated at the end of the $13^{\text {th }}$ day, John, Alistair and Evan were still eating in excess of their estimated daily energy expenditure, even after having made up the deficit caused by the very high expenditure between the $4^{\text {th }}$ and 8 th days, although it was evident that the excess of intake over output was decreasing fairly rapidly. George, on the other hand, appeared to have reached a balance on the $13^{\text {th }}$ day and it might reasonably have been expected that the others would have done likewise within a comparatively short time. Iain too, was at a fairly constant level during the last 2 days, but it is impossible to translate his weight loss into terms of calories withdrawn from store because of the lack of information on water metabolism.

George, therefore, is the only subject from whose data conclusions based on the intake-output basis can, with any reasonable degree of certainty, be drawn. It should be noted that this subject was the only one other than John (who had to go to bed during the very active period as a result of mumps), who had been taking regular exercise during the winter and was therefore least affected by the strenuous physical activities of the $4^{\text {th }}$-8th experimental days. For him the difference between intake and output over the whole period was less than $3 \%$. The same degree of agreement might have been obtained by Evan had the experiment been continued for a longer period, but at the end of the $13^{\text {th }}$ day the difference amounted to $4 \%$. The net weight difference over the experimental period for all five subjects amounted to less than I $\mathrm{kg}$ and the estimated energy value of the food eaten exceeded the estimated energy expenditure by $3 \%$.

The results therefore show a satisfactory degree of agreement between energy intake, as food, and energy expenditure as determined by the Kofranyi-Michaelis analysis of activities. Had the subjects been more accustomed to the types of activity which they carried out between the $4^{\text {th }}$ and 8 th days it can be predicted that the day-to-day difference between intake and output would have been lessened. This last condition would be found in a study of subjects on heavy work continuously, as in some industries. 
I. The Kofranyi-Michaelis calorimeter was used to estimate the energy expenditure of five subjects over a period of 13 days, during 5 of which the subjects carried out tasks involving great energy expenditure.

2. The results were compared with the energy value of the food eaten during the same period.

3. A satisfactory agreement between these two estimates over this comparatively short period was found in spite of the fact that three subjects were affected by the severity of the work involved in some of the tasks for which they were not in training.

4. It is suggested that this technique might be used to estimate the energy expenditure of operatives, especially those engaged in heavy industry.

This experiment would have been impossible without the active co-operation of the subjects, Alistair, Evan, George, John and Iain. They cheerfully undertook the labours of walking under adverse conditions and the monotony of note-taking.

Dr H. E. Magee, Ministry of Health, kindly arranged the supply of two calorimeters from Germany.

We are grateful to Dr C. P. Stewart and the staff of the Clinical Laboratory, Edinburgh Royal Infirmary, for analyses of the food. The Edinburgh Royal Infirmary, and the South-Eastern Regional Hospital Board, Scotland, lent us much valuable domestic equipment. Dr B. Woolf and Miss Joyce Thomson advised and helped with the calculations. Finally, we wish to thank the Medical Research Council for a financial grant which covered the cost of the board for the subjects.

\section{REFERENCES}

Canadian Council on Nutrition (1950). Canad. Bull. Nutrit. 2, no. I.

Droese, W., Kofranyi, E., Kraut, H. \& Wildeman, L. (1949-50). Arbeitsphysiologie, 14, 63.

Food and Agriculture Organization of the United Nations (1950). Nutritional Studies, no. 5. Washington, D.C.: Food and Agriculture Organization of the United Nations.

Kofranyi, E. \& Michaelis, H. F. (r940). Arbeitsphysiologie, Ir, 148.

Lehmann, G., Müller, E. A. \& Spitzer, H. (1949-50). Arbeitsphysiologie, r4, 166.

Orr, J. B. \& Leitch, I. (1937-8). Nutr. Abstr. Rev. 7, 509.

Orsini, D. \& Passmore, R. (1951). F. Physiol. I15, 95. 